\title{
Clearance effects of the Pacific oyster Crassostrea gigas on the fish-killing algae Chattonella marina and Chattonella antiqua
}

\author{
Sou Nagasoe ${ }^{1,2}$, Kengo Suzuki ${ }^{1}$, Tatsuya Yurimoto ${ }^{1,3}$, Reiko Fuseya ${ }^{1,6}$, \\ Tsuyoshi Fukao ${ }^{1}$, Toshifumi Yamatogi ${ }^{4,5}$, Katsunori Kimoto ${ }^{1}$, Yukio Maeno ${ }^{1,3, *}$ \\ ${ }^{1}$ Seikai National Fisheries Research Institute, Fisheries Research Agency, Nagasaki, Nagasaki 851-2213, Japan \\ ${ }^{2}$ National Center for Stock Enhancement, Fisheries Research Agency, Miyazu Station, Miyazu, Kyoto 626-0052, Japan \\ ${ }^{3}$ Japan International Research Center for Agricultural Sciences, Tsukuba, Ibaraki 305-8686, Japan \\ ${ }^{4}$ Nagasaki Prefectural Institute of Fisheries, Nagasaki, Nagasaki 851-2213, Japan \\ ${ }^{5}$ Nagasaki Prefectural Tsushima District Office, Fisheries Division, Tsushima, Nagasaki 817-8520, Japan
}

${ }^{6}$ Present address: National Research Institute of Fisheries Engineering, Fisheries Research Agency, Kamisu, Ibaraki 314-0408, Japan

\begin{abstract}
We exposed Pacific oysters Crassostrea gigas to the harmful algal species, Chattonella marina and C. antiqua, at various initial algal cell densities for up to $24 \mathrm{~h}$. None of the oysters died, even after exposure to high cell densities of both Chattonella species. Oysters filtered Chattonella from the aquarium water within $24 \mathrm{~h}$, depending on initial algal cell densities. The oyster clearance rates peaked at a specific cell density for each algal species (about 100 cells ml$^{-1}$ for C. marina and about 10 cells ml$^{-1}$ for $C$. antiqua). However, because of differences in cell sizes between the algal species, the algal biovolume per unit water volume varied widely at the same cell density. The relationships between clearance rates and biovolumes of exposed algae were similar between the 2 algal species; clearance rates by the oysters peaked at about $1.0 \times 10^{6} \mathrm{\mu m}^{3} \mathrm{~mm}^{-3}$. The filtration activity of the oysters was fundamentally affected by their exposure to algal biovolume and not algal cell density. No histological lesions were found after the oysters were exposed to either Chattonella species. Furthermore, immunohistological observations of the digestive glands of the oysters and analysis of their phytopigment content revealed that Chattonella cells that were cleared from the water during exposure entered the cytoplasm of the oyster digestive glands by phagocytosis.
\end{abstract}

KEY WORDS: Clearance rate $\cdot$ Raphidophyte $\cdot$ Harmful algae $\cdot$ Chattonella spp.

\section{INTRODUCTION}

Chattonella (Raphidophyceae) are harmful flagellate algae that kill many wild and farmed fishes in coastal waters around the world (Landsberg 2002). The first report of massive blooms of Chattonella (C. marina) accompanied by mass mortality of fish was from the Malabar Coast, India (Subrahmanyan 1954 as cited in Imai et al. 1998). Red tides of Chattonella causing massive fish kills have been recorded thereafter in Japan, North and South America, Europe, China, Australia, Southeast Asia and Russia (Okaichi 1989, Hallegraeff et al. 1998, Marshall \& Hallegraeff 1999, BackeHansen et al. 2001, Bourdelais et al. 2002). Among the
6 Chattonella species with global distributions (Hallegraeff \& Hara 2003), in Japan C. marina and C. antiqua caused particularly severe damage to fish aquaculture in the Seto Inland Sea from the 1970s through the mid1980s (Imai et al. 1998, 2006). After the 1990s, red tide frequencies of these species decreased in this area (Imai et al. 2006), but gradually increased in Ariake and Yatsushiro bays in Kyushu in southern Japan. Recently, mass mortalities of fish and shellfish during the bloom periods of both species have been major concerns around these bays. Because red tide outbreaks in these areas are often accompanied by water column anoxia and rising water temperature, the environmental factors that specifically affect the mortality 
of marine organisms have not yet been conclusively determined.

The genus Chattonella is widely known to be toxic to fish and is especially harmful to young yellowtail Seriola quinqueradiata Temminck \& Schlegel (Shimada et al. 1983, Toyoshima et al. 1985). However, there is no universal agreement on the mechanisms of toxicity of this genus (Landsberg 2002). One proposed mechanism is the production of brevetoxin or brevetoxinlike compounds, which have been demonstrated in laboratory cultures of C. marina and C. antiqua (Ahmed et al. 1995, Khan et al. 1996). A second proposed mechanism is that Chattonella cells also generate reactive oxygen species (ROS) such as superoxide anions $\left(\mathrm{O}_{2}^{-}\right)$, hydrogen peroxide molecules $\left(\mathrm{H}_{2} \mathrm{O}_{2}\right)$ and hydroxyl radicals $(\cdot \mathrm{OH})$ (Shimada et al. 1989, 1991, 1993, Oda et al. 1992a,b, 1994, 1995, 1997, 1998, Tanaka et al. 1992, 1994, Kawano et al. 1996). These products may damage the cell membranes of fish, especially the cell membrane of gill tissue, leading to death. A third proposed mechanism is that the mucus present on Chattonella cell surfaces adheres to the gills of the fish and kills them by interfering with their respiration (Hada 1974, Jenkinson et al. 2007).

Although the toxic effects of Chattonella species have been well studied in marine fishes, there are few studies on the effects of Chattonella on bivalves (Kim et al. 2004, Keppler et al. 2006, Alexander et al. 2008), and no studies have examined the clearance activity of bivalves when they are exposed to various cell densities of Chattonella species. We observed the survival of oysters after outbreaks of Chattonella blooms in Ariake Bay and know of no report of massive mortality of oysters during the blooms.

The aims of the present study were to determine whether oysters are as adversely affected by Chattonella as are fishes, and whether oysters can filter Chattonella cells. To achieve these aims, we exposed Pacific oysters Crassostrea gigas to Chattonella marina and Chattonella antiqua under laboratory conditions.

\section{MATERIALS AND METHODS}

Algal strains and oyster. The algal cultures used in the present study included Chaetoceros gracilis, Chattonella antiqua and Chattonella marina. As bivalve feed, concentrated C. gracilis diatoms were supplied by the Tasaki Institute for Marine Biological Research. These diatoms were stored in the dark at $4{ }^{\circ} \mathrm{C}$ for up to $2 \mathrm{wk}$ until used for the experiments. C. marina (strain CmA10707) and C. antiqua (CaA24808) were isolated from blooms in Isahaya Bay, Nagasaki, Japan $\left(32^{\circ} 53^{\prime} 20^{\prime \prime} \mathrm{N}, 130^{\circ} 12^{\prime} 00^{\prime \prime} \mathrm{E}\right)$ in July 2007 and August 2008, respectively. The stock cultures of each were maintained in $100 \mathrm{ml}$ flasks containing $50 \mathrm{ml}$ modified SWM-3 medium (Yamasaki et al. 2007) at $20^{\circ} \mathrm{C}$ under $150 \mu \mathrm{mol}$ photons $\mathrm{m}^{-2} \mathrm{~s}^{-1}$ with a $14 \mathrm{~h}$ light:10 h dark cycle. We identified these 2 strains as genus Chattonella by the PCR assay developed by Connell (2002) (see Fig. A1 in Appendix 1). It was recently proposed that $C$. marina and $C$. antiqua could be the same species, based on genetic diversity studies (Connell 2000, Hosoi-Tanabe et al. 2006, Kamikawa et al. 2007, Demura et al. 2009). However, the differences in morphological features between these 2 Chattonella species, especially cell volume (Table 1), provided an obvious distinction during the present study. Therefore, we treated the 2 strains as separate species, which were easily distinguishable under an inverted optical microscope. The morphological features of these strains, listed in Table 1, resembled those observed by Hosoi-Tanabe et al. (2006) and Demura et al. (2009); C. antiqua was relatively oblate and had a posterior tail (Fig. 1a), and C. marina was oblong to obovoid and also had a posterior tail (Fig. 1b). C. antiqua cells were the largest among the algae used in the present study (Fig. 1, Table 1). The cell volumes were calculated by the method of Sun \& Liu (2003).

The oysters used for the experiments had shell lengths of 6.0 to $7.5 \mathrm{~cm}$ and were farmed in Nagasaki, Japan. Prior to the experiments, the oysters were kept at $23^{\circ} \mathrm{C}$ in an indoor tank filled with seawater that was filtered first through sand and then through a $5 \mu \mathrm{m}$ pore size cartridge filter (Micro-Wynd II Filter Cartridge, CUNO K.K.). The stored oysters were fed a mixture of Chaetoceros gracilis and a commercial artificial feed (Nosan Shellfish Micron M1, Nosan).

Toxicity of Chattonella strains to fish. To determine toxicity to fish, Chattonella marina and C. antiqua were each exposed to black rockfish Sebastes inermis. Twenty fish apiece were placed into 2 polycarbonate cylinders $(35 \mathrm{~cm}$ diameter $\times 30 \mathrm{~cm}$ height), each containing $27 \mathrm{l}$ of filtered seawater $(5 \mu \mathrm{m}$ pore size, MicroWynd II Filter Cartridge, CUNO K.K.). A 31 volume of C. marina culture was inoculated into 1 test cylinder, 

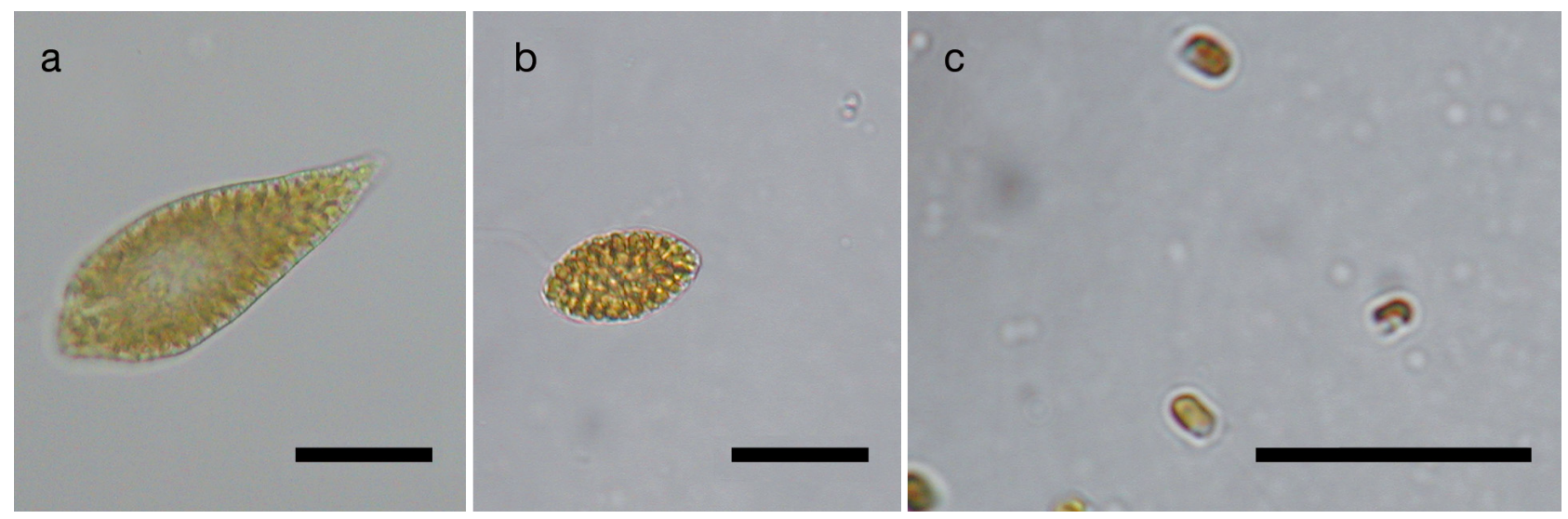

Fig. 1. Optical micrographs of (a) Chattonella antiqua, (b) C. marina and (c) Chaetoceros gracilis used in the present study (scale bars $=30 \mu \mathrm{m})$

and 31 of fresh modified SWM-3 medium was added to the other cylinder as the control. The inoculum size was adjusted to yield about $3.0 \times 10^{3}$ cells $\mathrm{ml}^{-1}$ of the phytoplankton. The seawater in the cylinders was gently aerated to ensure homogeneous distribution of the cells. After $24 \mathrm{~h}$, the number of dead fish was determined for each chamber. For assessing toxicity of C. antiqua to fish, the experimental design was the same as above, except that 10 fish were used. This experiment was not replicated.

Experimental design for the exposure experiments. To examine the effect of Chattonella species on the filtration ability of adult oysters, oysters $(\mathrm{n}=6$ oysters for each cell density) were exposed to 5 initial cell densities for each of 3 phytoplankton species (Chaetoceros gracilis: $1.5 \times 10^{5}, 3.0 \times 10^{5}, 1.0 \times 10^{6}, 2.0 \times 10^{6}$ and $3.0 \times$ $10^{6}$ cells ml ${ }^{-1}$; Chattonella marina and C. antiqua: $5.0 \times$ $10^{2}, 1.0 \times 10^{3}, 2.5 \times 10^{3}, 5.0 \times 10^{3}$ and $1.0 \times 10^{4}$ cells $\mathrm{ml}^{-1}$ ). Chaetoceros gracilis, which is generally prey for bivalves, was used as a control in the feeding experiments. The clearance rate of individual oysters was calculated from hourly measurements of algal cell density in each aquarium (see below).

Exposure procedure. Each aquarium $(15 \mathrm{~cm}$ length $\times 15 \mathrm{~cm}$ width $\times 24 \mathrm{~cm}$ height) contained 21 of filtered seawater, and 1 oyster was placed into each of the 6 aquaria (these aquaria are hereafter called the 'exposure section') (Fig. 2). Similarly, 1 aquarium without any oysters (hereafter called the 'control section') was set up so that the conditions of the phytoplankton cells could be observed, because spindle-shaped active cells of Chattonella marina and $C$. antiqua have harmful effects on fish, but spherical and nonmotile cells do not (Tanaka et al. 1992, Hishida et al. 1998). The oysters were stored under dim light at $24 \pm 1^{\circ} \mathrm{C}$ ), and this temperature was maintained by temperature-controlled water $\left(23^{\circ} \mathrm{C}\right)$ that flowed through an outer container $(55 \mathrm{~cm}$ length $\times$ $85 \mathrm{~cm}$ width $\times 20 \mathrm{~cm}$ height, Fig. 2). After the oysters were placed in the aquaria, they were left to stand for

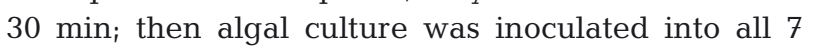
aquaria ( $n=6$ aquaria in the exposure section and $n=$ 1 aquarium in the control section) at 5 different initial cell densities (see above) for each aquarium. Before adding the inoculum, an amount of seawater equal to the inoculum volume was drained from each aquarium. The seawater in the aquaria was gently aerated to ensure homogeneous distribution of phytoplankton. Hourly measurements of phytoplankton were continued until almost no algal cells remained in the aquaria or for up to $24 \mathrm{~h}$, whichever came first. At the end of all of the exposure experiments, the dry soft body weights of the oysters were measured. Body tissues were dried to a constant weight for 24 to $72 \mathrm{~h}$ at $60^{\circ} \mathrm{C}$. The rates of phytoplankton clearance by the oysters were calculated from the hourly decrease in cell density of phytoplankton according to the following equation:

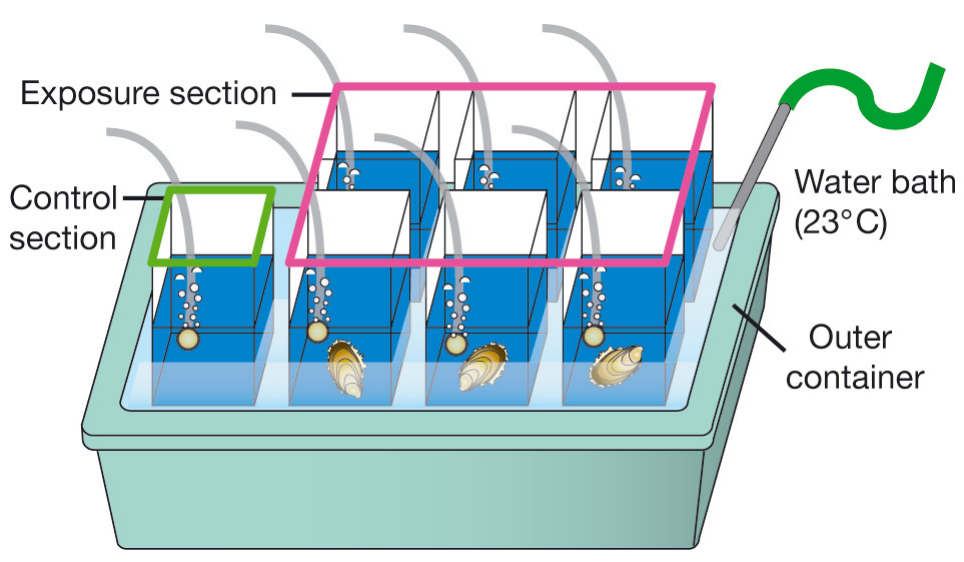

Fig. 2. Diagram of the experimental setup 


$$
C l=\frac{V \cdot\left(\ln N_{t}-\ln N_{t+\Delta t}\right)}{\mathrm{n} \cdot \Delta t} \times \frac{1}{W}
$$

where $\mathrm{Cl}$ is the clearance rate $\left(\mathrm{l} \mathrm{h}^{-1} \mathrm{~g}^{-1}\right.$ dry weight [DW]), $V$ is the volume of water in the aquarium (l), $N_{t}$ is the cell density of phytoplankton at the beginning of the period (cells ml-1 ${ }^{-1}, N_{t+\Delta t}$ is the cell density of phytoplankton at the end of the period (cells ml-1), $\mathrm{n}$ is the number of oysters, $\Delta t$ is the duration of the time interval $(t, t+\Delta t)(\mathrm{h})$ and $W$ is the dry soft body weight of the oysters $(\mathrm{g})$. The values of the selectable variables were exactly $\mathrm{n}=1, \Delta t=1$, and $V=2$.

Determination of Chaetoceros gracilis cell density. C. gracilis cell densities were determined by measuring in vivo chlorophyll a (chl a) fluorescence with a fluorometer (model 8000-010, Turner Designs), because counting this minuscule organism under an inverted light microscope is so complex and difficult. Although the number of $C$. gracilis cells per unit water volume did not increase during these experiments (as confirmed by direct count with a light microscope), the in vivo chl a fluorescence per unit water volume increased slightly with time. This increase was caused by an increase in the chl a content per cell of the diatom. We therefore calculated a correction coefficient to keep the in vivo chl a fluorescence of the control section constant:

$$
\text { Correction coefficient }=F_{0} / F_{t}
$$

where $F_{0}$ is the in vivo chl a fluorescence of C. gracilis in the control section at the beginning of exposure and $F_{t}$ is the in vivo chl a fluorescence after time $t(\mathrm{~h})$. We corrected the cell density values of the exposure section by multiplying them by the correction coefficient.

Determination of Chattonella marina and $\boldsymbol{C}$. antiqua cell density. The cell densities of the 2 Chattonella species were determined by using an inverted light microscope (ECLIPSE E400, Nikon) at 40× magnification. Every hour, 1.0 to $3.5 \mathrm{ml}$ samples were collected from each aquarium and whole vegetative cells of $C$. marina or C. antiqua in 5 to $1000 \mu \mathrm{l}$ subsamples were counted in a Sedgwick-Rafter counting chamber.

Analysis of phytopigment in the digestive glands of oysters and immunohistological observation of oyster tissue. The digestive glands were analyzed for the presence of phytopigments to determine whether phytoplankton cells had entered the digestive tracks of the oysters. The oysters were kept in an indoor tank and their gut contents were cleared in constantly flushed, aerated, algal-free seawater $\left(23^{\circ} \mathrm{C}\right.$, salinity of 30) for 1 wk before introduction of the test alga. We placed 1 oyster into each of 15 aquaria, each containing 21 of filtered seawater. These 15 aquaria were divided into 3 sets of 5 to expose the oysters to Chaetoceros gracilis (initial cell density: $3.0 \times 10^{5}$ cells $\left.\mathrm{ml}^{-1}\right)$, Chattonella marina $\left(5.0 \times 10^{3}\right.$ cells $\left.\mathrm{ml}^{-1}\right)$ or
C. antiqua $\left(2.5 \times 10^{3}\right.$ cells ml $\left.{ }^{-1}\right)(\mathrm{n}=5$ oysters for each alga). After $12 \mathrm{~h}$, the exposed oysters were dissected and a piece of digestive gland was isolated from each. The analyses of phytopigments ( $\mathrm{chl} a$ and phaeophytin) in the digestive glands were performed according to the method of Numaguchi (2001). Each piece of the wet digestive gland tissue was weighed, soaked in $10 \mathrm{ml}$ of $90 \%$ acetone in the dark at $4^{\circ} \mathrm{C}$ for $24 \mathrm{~h}$ and then centrifuged at $2300 \times g$ for $20 \mathrm{~min}$ to extract the pigment. About $3 \mathrm{ml}$ of the supernatant was measured with a spectrophotometer at wavelengths of 665 and $750 \mathrm{~nm}$ to determine chl a content. To determine the phaeophytin content another $5 \mathrm{ml}$ of the supernatant was analyzed at the same wavelengths after addition of $50 \mu \mathrm{l}$ of $4 \mathrm{~N} \mathrm{HCl}$. The chl $a$ and phaeophytin contents $\left(\mu \mathrm{g} \mathrm{g}^{-1}\right)$ were determined based on the equations developed by Strickland \& Parsons (1968), according to the following modified formulae:

$$
\begin{gathered}
\text { Chlorophyll } a=\frac{26.7 \cdot\left(E_{0}-E_{a}\right) \cdot v}{M \cdot l} \\
\text { Phaeophytin }=\frac{26.7 \cdot\left(1.7 E_{a}-E_{0}\right) \cdot v}{M \cdot l}
\end{gathered}
$$

where $E_{0}$ is the difference between the absorbancies at 665 and $750 \mathrm{~nm}, E_{a}$ is the difference between the absorbancies at these wavelengths after addition of $50 \mu \mathrm{l}$ of $4 \mathrm{~N} \mathrm{HCl}$ to the supernatant, $V(\mathrm{ml})$ is the volume of acetone used for the pigment extraction, $M$ (g) is the weight of the digestive gland sample, and 1 $(\mathrm{cm})$ is the path length of the quartz cell. In addition to the 15 exposed oysters, the digestive glands of 5 fasted oysters were analyzed in the same manner as the initial control.

We also examined whether Chattonella cells could damage oyster tissue. The oysters used for this histological and immunohistochemical examination were the same oysters that were used for the above phyto-pigment analysis. The gills, mantle and digestive gland of the oysters were fixed in $10 \%$ formalin in seawater, dehydrated and embedded in paraffin. The oysters that were exposed to Chaetoceros gracilis $(3.0 \times$ $10^{5}$ cells ml ${ }^{-1}$ ) were used as the negative control and the fasted oysters were used as the initial control; all groups were processed in the same manner. For histological examination, $4 \mu \mathrm{m}$ thick paraffin sections of tissues were stained with Mayer's haematoxylin and eosin. For immunohistochemical analysis, the sections of digestive glands were treated with $\mathrm{H}_{2} \mathrm{O}_{2}$ in methanol $(0.02 \% \mathrm{v} / \mathrm{v})$ for $10 \mathrm{~min}$, rinsed in phosphatebuffered saline (PBS, pH 7.4, Nissui) and then treated with normal goat serum $(10 \% \mathrm{w} / \mathrm{v}$ in PBS) to block nonspecific antibody binding. Next, the sections of the digestive glands were treated with a primary antibody 
(rabbit serum anti-Chattonella marina or anti- $C$. antiqua) at a dilution of 1:500 in PBS for $1 \mathrm{~h}$ at $37^{\circ} \mathrm{C}$, while the control sections were incubated with normal unimmunized rabbit serum at the same dilution. The sections were washed with PBS and then treated with a biotinylated goat antibody to rabbit immunoglobulin G (IgG) (SAB Kit, Histofine, Nichirei) for $10 \mathrm{~min}$ at room temperature. The sections were washed again with PBS and treated with streptavidin-peroxidase complex reagent (SAB Kit, Histofine) for $5 \mathrm{~min}$ at room temperature. Next, the sections were washed with PBS and then exposed to 3.3'-diaminobenzidine (DAB, Dako) as a substrate. The sections for immunohistochemistry were counterstained with Mayer's haematoxylin and dehydrated through graded levels of alcohol. The sections were then cleared with xylene and mounted on a MKG-S slide (Matsunami Glass Industries). Observations of the sections under an inverted light microscope (ECLIPSE E400, Nikon) were recorded, and the localization patterns were determined based on the intensity of negative (-) and positive (+) immunostaining.

Statistical analysis. Data for phytopigments in digestive glands were analyzed for statistically significant differences $(p<0.05)$ between the initial control and each experimental section by means of a $t$-test using SPSS 10.0 for Windows (SPSS). The values for these data are expressed as mean $\pm \mathrm{SD}$.

\section{RESULTS}

\section{Mortality of fish and oysters}

No black rockfish in any of the control cylinders had died after $24 \mathrm{~h}$. In contrast, 4 of 20 fish exposed to Chattonella marina (20\%) and 7 of 10 fish exposed to C. antiqua ( $70 \%$ ) died within $24 \mathrm{~h}$. No oysters exposed to C. marina or C. antiqua had died after $24 \mathrm{~h}$.

\section{Time-dependent decline in algal cell density with feeding by oyster}

At low initial Chaetoceros gracilis cell densities $\left(1.5 \times 10^{5}\right.$ and $3.0 \times 10^{5}$ cells $\left.\mathrm{ml}^{-1}\right)$, the oysters filtered and cleared the algal cells within $2 \mathrm{~h}_{\text {; }}$ the algal cell densities in the aquaria declined to about $0.3 \%$ of each initial exposure density (Fig. 3a,b). At $1.0 \times 10^{6}$ cells $\mathrm{ml}^{-1}$, the cell densities in most of the aquaria began to decrease just after the cells were inoculated, and almost all of the cells had been cleared within $14 \mathrm{~h}$; the algal cell densities declined to $2.3 \%$ of the initial exposure density (Fig. 3c). At high cell densities $\left(2.0 \times 10^{6}\right.$ and $3.0 \times 10^{6}$ cells $\mathrm{ml}^{-1}$ ), this alga was slowly removed by oyster filtration until cell density reached about 1.5 to $2.5 \times 10^{6}$ cells $\mathrm{ml}^{-1}$ and then was removed relatively quickly once the cell density became lower (Fig. 3d,e).
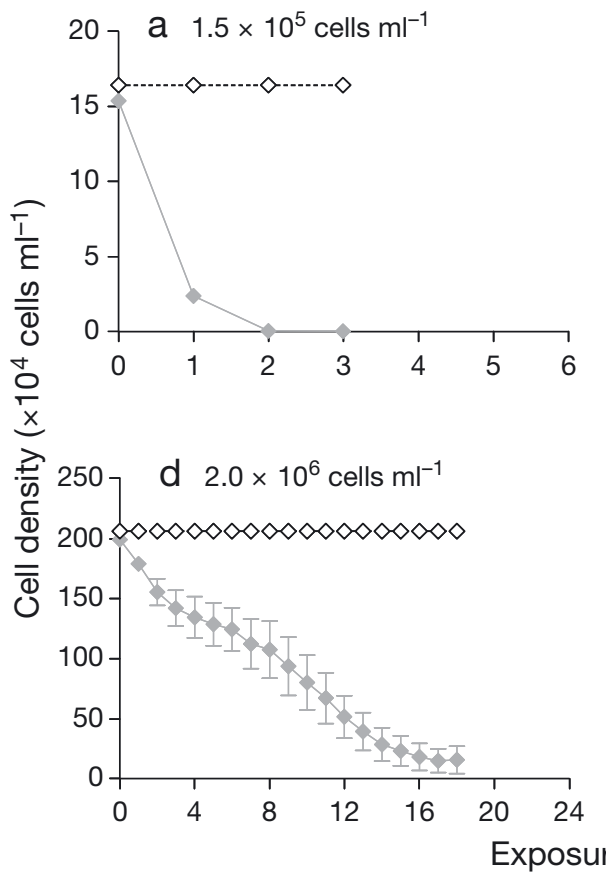

Fig. 3. Chaetoceros gracilis. Cell density over time with or without feeding by 1 oyster in 21 of seawater at various initial algal densities $(\mathrm{a}-\mathrm{e})$. The controls indicate density of the diatom numbers in the aquaria without any oysters. Error bars indicate SE of
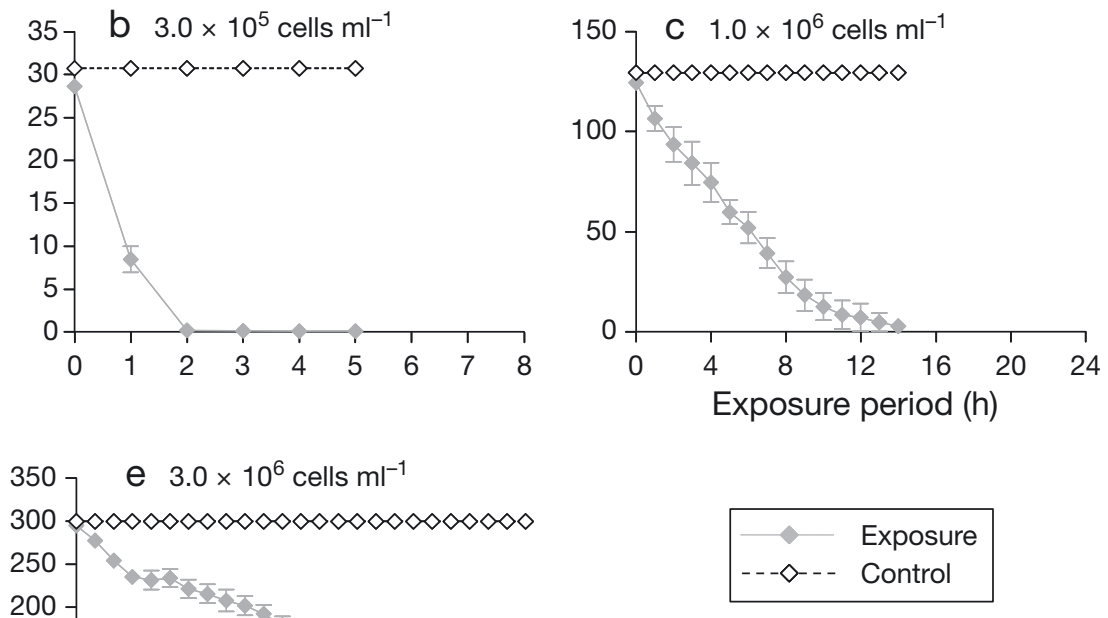

the mean $(\mathrm{n}=6)$ 
Within $24 \mathrm{~h}$, the oysters cleared most $C$. gracilis at high initial cell densities $\left(2.0 \times 10^{6}\right.$ and $\left.3.0 \times 10^{6} \mathrm{cells} \mathrm{ml}^{-1}\right)$; the algal cell densities in aquaria declined to 6.8 and $13.5 \%$ of initial values, respectively (Fig. $3 \mathrm{~d}, \mathrm{e}$ ).

Interestingly, every observed cell of Chattonella marina in the control aquaria had a slight loss of motility (data not shown), but no morphological defects were observed. In the exposure sections, at initial densities of $5.0 \times 10^{2}$ to $5.0 \times 10^{3} \mathrm{cells} \mathrm{ml}^{-1}$, the oysters filtered nearly all of the $C$. marina cells just after inoculation into the aquaria; the algal cell densities in aquaria declined to below $0.3 \%$ of each initial exposure density (Fig. $4 \mathrm{a}-\mathrm{d}$ ). At an initial density of $1.0 \times 10^{4}$ cells $\mathrm{ml}^{-1}$, oyster filtration slowly removed the cells until they reached a density of 7.0 to $9.0 \times 10^{3}$ cells ml $^{-1}$ (time span: up to $8 \mathrm{~h}$ ), and then clearance proceeded relatively quickly once the cell density became lower. Within $24 \mathrm{~h}$, oyster filtration had decreased the cell densities of C. marina to $6.8 \%$ of initial exposure densities (Fig. 4e).

As with Chattonella marina, every C. antiqua cell observed in the control aquaria had a slight loss of motility, but no morphological defects were observed. In the exposure sections, oysters filtered fewer C. antiqua cells than they filtered the other 2 algal species used in the present study. At initial densities of $5.0 \times$ $10^{2}$ cells ml ${ }^{-1}$, oysters filtered the cells to $11.9 \%$ of initial exposure density (Fig. 4a). Furthermore, at initial cell densities of $1.0 \times 10^{3}$ and $2.5 \times 10^{3}$ cells ml $^{-1}$, the cells decreased in all aquaria, but 33.7 and $25.1 \%$ of initial exposure densities remained at $24 \mathrm{~h}$ (Fig. 4b,c). At $5.0 \times 10^{3} \mathrm{cells} \mathrm{ml}^{-1}$, the oysters filtered this alga, but at $24 \mathrm{~h} 60.0 \%$ of the initial exposure densities remained in the water (Fig. 4d). At $1.0 \times 10^{4} \mathrm{cells} \mathrm{ml}^{-1}$, $87.4 \%$ of the initial exposure density remained in the water column at $24 \mathrm{~h}$ (Fig. $4 \mathrm{e}$ ).

\section{Algal clearance rates}

Oyster clearance of phytoplankton was highest at a specific cell density that varied among the algal species used in the present study: about 100 cells ml$^{-1}$ for Chattonella marina, about 10 cells ml $^{-1}$ for $C$. antiqua and about 10000 cells ml $^{-1}$ for Chaetoceros gracilis (Fig. $5 a)$. Moreover, the clearance rates of the oysters gradually declined with increases in algal cell density above these specific values (Fig. 5a). Because cell volume was clearly different among the algal species used in the present study (Table 1), we also examined the relationships between the clearance rates and phytoplankton biovolumes. To determine the biovolumes, we converted the cell density of each alga to cell volume per unit water volume. The peak clearance rate was obtained at a biovolume of about $1.0 \times 10^{6} \mu^{3}$ $\mathrm{mm}^{-3}$ for all 3 species of algae (Fig. $5 \mathrm{~b}$ ); however, the
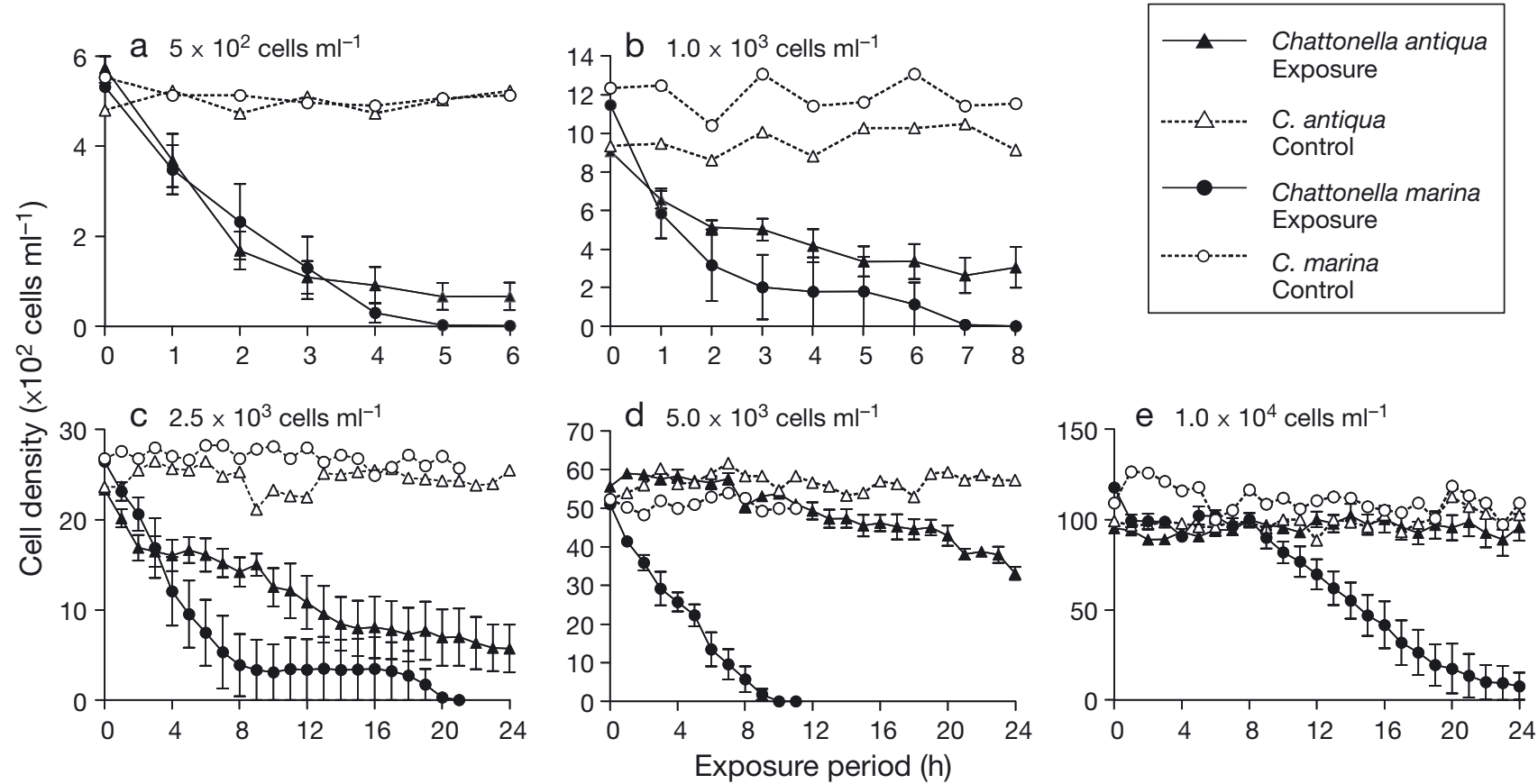

Fig. 4. Chattonella antiqua and C. marina. Cell densities over time with or without feeding by 1 oyster from 21 of seawater. The panels show the initial algal cell densities: (a) $5.0 \times 10^{2}$, (b) $1.0 \times 10^{3}$, (c) $2.5 \times 10^{3}$, (d) $5.0 \times 10^{3}$ and (e) $1.0 \times 10^{4} \mathrm{cells} \mathrm{ml}^{-1}$. The controls indicate fluctuation of $C$. antiqua and $C$. marina cell densities in the aquaria without any oysters. Error bars indicate SE of the mean $(\mathrm{n}=6)$ 


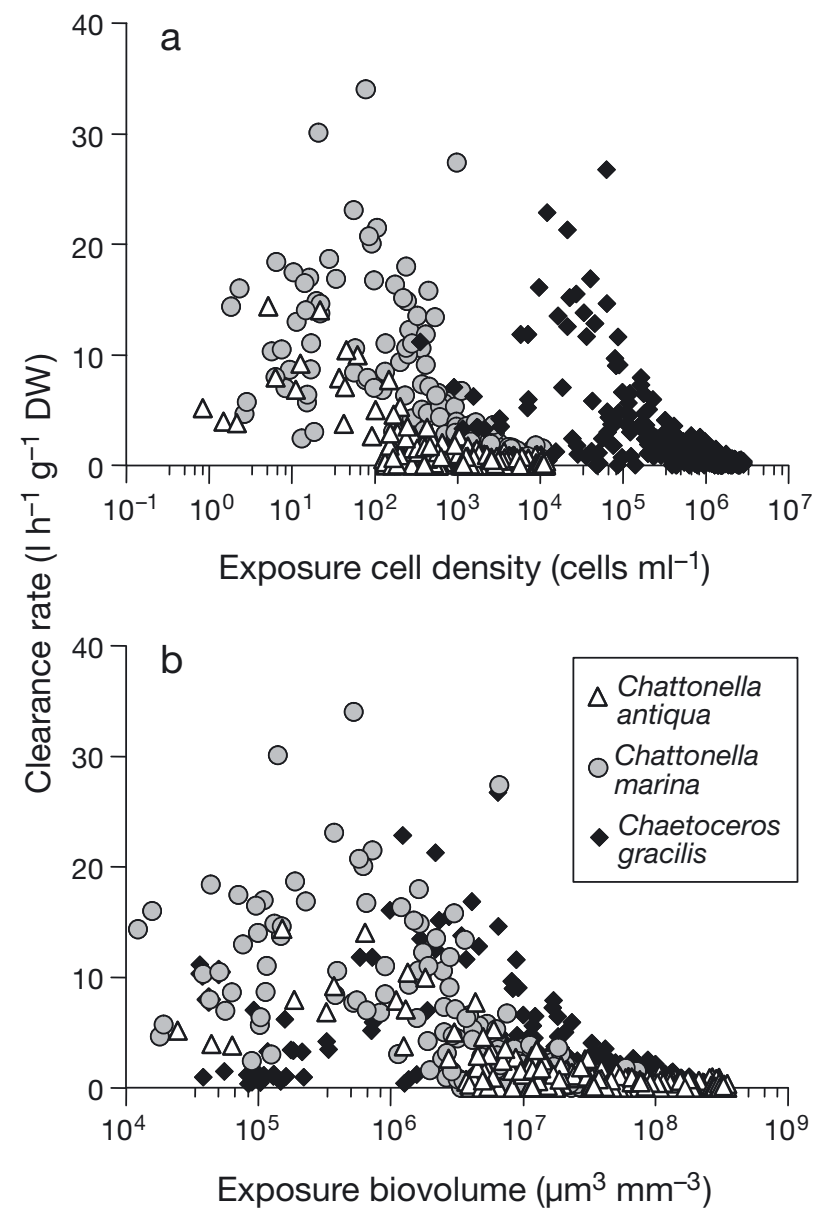

Fig. 5. Chattonella antiqua, C. marina and Chaetoceros gracilis. The effect of (a) cell density and (b) biovolume of the 3 algal species on clearance rates by oysters. The density of cells was defined as the average of the densities of phytoplankton cells at the beginning $\left(N_{t}\right)$ and end $\left(N_{t+\Delta t}\right)$ of each $1 \mathrm{~h}$ time period

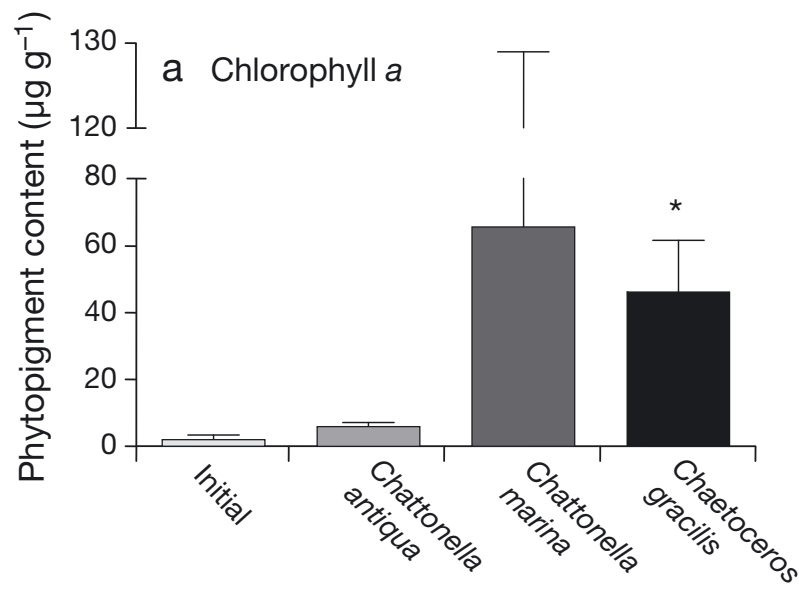

peak clearance rate was remarkably lower for oysters exposed to C. antiqua (14.4 $\left.\mathrm{l} \mathrm{h}^{-1} \mathrm{~g}^{-1} \mathrm{DW}\right)$ than for oysters exposed to C. marina $\left(34.0 \mathrm{l} \mathrm{h}^{-1} \mathrm{~g}^{-1} \mathrm{DW}\right)$ and $C$. gracilis (26.7 $\left.1 \mathrm{~h}^{-1} \mathrm{~g}^{-1} \mathrm{DW}\right)$.

Phytopigment in the oyster digestive glands and immunohistological observations of the oyster tissue

The amounts of chl $a$ and phaeophytin in oysters exposed to Chattonella marina $(65.7 \pm 55.5$ and $376.1 \pm$ $201.7 \mathrm{\mu g} \mathrm{g}^{-1}$, respectively; mean $\pm \mathrm{SD}, \mathrm{n}=5$ ) or Chaetoceros gracilis $\left(46.2 \pm 34.7\right.$ and $\left.568.8 \pm 414.5 \mu^{-1} \mathrm{~g} \mathrm{~g}^{-1}\right)$ were significantly higher than those in feed-deprived oysters $\left(2.0 \pm 2.9\right.$ and $8.3 \pm 3.4 \mu^{-1} g^{-1}$, initial control), except for chl $a$ in $C$. marina, which was higher than the control, but the difference was not significant ( $t$-test: $\mathrm{p}=0.061)$ due to variability among replicates (Fig. 6). The oysters filtered very few Chattonella antiqua cells during the $12 \mathrm{~h}$ exposure period; the cell density of this alga decreased from $2564 \pm 145$ to $2275 \pm$ 90 cells $\mathrm{ml}^{-1}$ (mean $\pm \mathrm{SD}, \mathrm{n}=5$ ). Consequently, the phytopigment content in digestive glands of the oysters was relatively low. Nevertheless, the amounts of chl $a$ and phaeophytin in the oysters exposed to $C$. antiqua $\left(6.0 \pm 2.6\right.$ and $28.1 \pm 19.5 \mu \mathrm{g} \mathrm{g}^{-1}$, respectively) were more than triple the amounts in the unfed control oysters, though these differences were not significant.

No histological lesions were found in the gills, mantle and digestive gland of the oysters exposed for $12 \mathrm{~h}$ in either the experimental groups or control groups. Immunohistological analysis of the digestive glands of the oysters detected strong immunoperoxidase positive reactions in all of the oysters exposed to Chattonella marina and C. antiqua. Immunoreactivity was confined exclusively to the cytoplasm of the epithelial

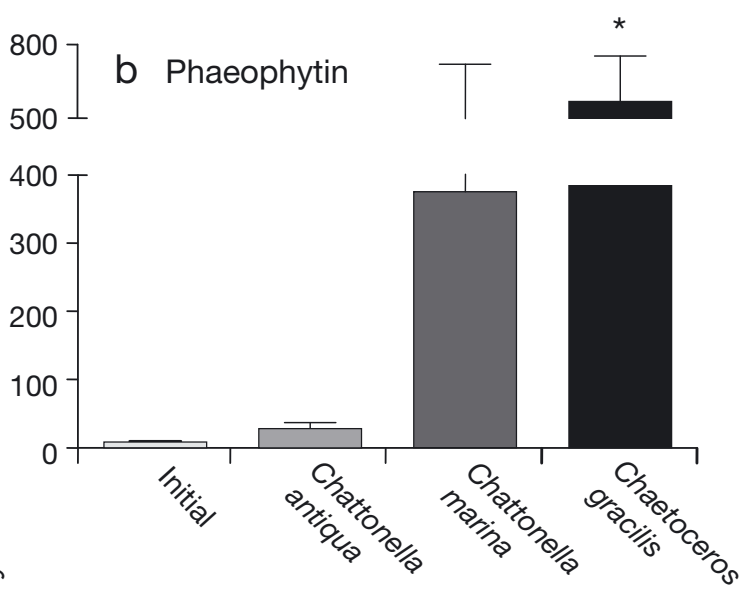

Fig. 6. Crassostrea gigas. Content $\left({\mu g^{-1}}^{-1}\right)$ of (a) chlorophyll a and (b) phaeophytin in digestive glands of oysters after exposure to various phytoplankton for $12 \mathrm{~h}$. The initial density was the amount of phytopigments in the digestive glands of the oysters before exposure to experimental algae. Data are expressed as mean \pm SD $(n=5)$ *: Significant difference from initial control oysters in $t$-test $(\mathrm{p}<0.05)$ 

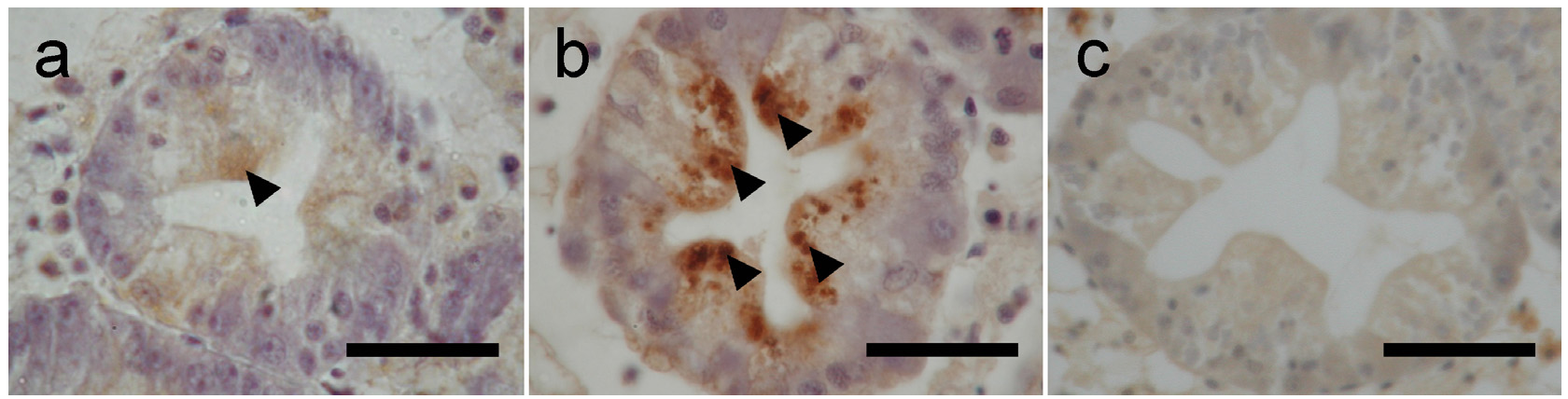

Fig. 7. Crassostrea gigas. Immunoperoxidase-stained epithelial cells of digestive glands of oysters $12 \mathrm{~h}$ after they were exposed to (a) Chattonella antiqua, (b) C. marina and (c) Chaetoceros gracilis. Strongly immunopositive localization (arrowheads) appeared in the cytoplasm of epithelial cells counterstained with Mayer's haematoxylin (scale bars $=20 \mu \mathrm{m}$ )

cells of the digestive gland (Fig. 7). However, no immunoreactions were observed in either the initial or negative control oysters.

\section{DISCUSSION}

In the present study, 20 and $70 \%$ of black rockfish died after $24 \mathrm{~h}$ exposure to $3.0 \times 10^{3}$ cells ml $^{-1}$ of Chattonella marina and C. antiqua, respectively. However, there was no mortality among the oysters that were exposed to $1.0 \times 10^{4}$ cells ml ${ }^{-1}$ of either Chattonella species for $24 \mathrm{~h}$. Moreover, no histological damage was found in the gills, mantles, or digestive glands of the oysters. These observations show that Chattonella cells do not directly harm oysters via mechanisms such as production of brevetoxin, brevetoxin-like compounds or ROS. Keppler et al. (2006) reported that another Chattonella species, C. subsalsa, has sublethal effects on the oyster Crassostrea virginica. Direct exposure to C. subsalsa caused lysosome destabilization of $C$. virginica, as did exposure to at least 1 Chattonella toxin, brevetoxin (Keppler et al. 2006). Lysosome damage can affect the ability of cells to survive various stressors, because this organelle is involved in cell defense and repair (Ringwood et al. 1998). However, the lysosomal destabilization is a sensitive physiological indicator of several types of stressors in oysters in both field and laboratory settings (Ringwood et al. 1998). Therefore, it is uncertain whether the lysosomal destabilization of oysters observed by Keppler et al. (2006) was caused by C. subsalsa brevetoxin or the other stressors during incubation. Baden (1989) and Plakas et al. (2002) noted that brevetoxins are lipid-soluble polyether molecules that are readily accumulated and metabolized by bivalves. Furthermore, neither laboratory nor field data indicate that agents toxic to fish (such as brevetoxins or ROS) can be produced in sufficiently high levels during Chattonella blooms to cause fish gill damage or fish mortality (Tang et al. 2005, Woo et al. 2006). Thus, our observations support the conclusions reported by previous studies that Chattonella toxins (such as brevetoxins and ROS) have little effect on fish and bivalve mortality (Baden 1989, Plakas et al. 2002, Tang et al. 2005, Woo et al. 2006).

Suffocation due to clogging of gills by algal cells has been proposed as one of the mechanisms of fish death induced by Chattonella (Hada 1974, Jenkinson et al. 2007). Hishida et al. (1998) reported the tolerances to C. marina of 3 cultured fishes to be 100, 33 and $0 \%$ for yellowtail, red sea bream Pagrus major and Japanese flounder Paralichthys olivaceus, respectively. These differences in mortality were caused by the different oxygen requirements of the fish species and by their physiological responses to hypoxia; yellowtail has the highest oxygen requirement among these 3 species (Hishida et al. 1998). Hishida (1999) also examined differences in tolerance to C. marina among the same 3 fishes from the perspective of gill structure. Yellowtail has the highest density of secondary gill lamellae among the 3 species, followed by red sea bream and Japanese flounder. The density of secondary gill lamellae indicates the sensitivity of the fish to suspended particles; yellowtail is the most susceptible to suspended particles among the 3 species (Hishida 1999). In other words, Chattonella-resistant organisms are strong enough to endure severe hypoxic conditions and have a less-clogging gill structure. Correspondingly, oysters should be resistant to Chattonella because bivalves generally show variable tolerance to hypoxic/anoxic conditions (de Zwaan et al. 1995, 2002, de Zwaan \& Eertman 1996). Furthermore, bivalve gills act not only as respiratory organs but also as filterfeeding organs. Suspended particles on the surfaces of bivalve gills are transferred to the mouth by gill ciliary movement. Thus, suspended particles affect oysters less than they affect fish. This is probably why we found no mortality among oysters that were exposed to Chattonella in the present study. 
Differences in cell volume among algal species at the same cell density cause wide variation in the algal biovolume per unit water volume. When the cell density of each alga was converted to biovolume per unit water volume, the relationships between clearance rates and the exposed algal biovolumes were similar among all of the experiments, irrespective of algal species. The peak clearance rates by the oysters occurred at biovol-

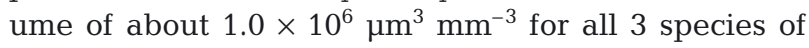
algae (Fig. 5b). Moreover, these results indicate that oysters can filter cells of both Chattonella species and Chaetoceros gracilis, the latter being a typical hatchery food for bivalves. These results also indicate that the filtration activity of the oysters is fundamentally more affected by the biovolume of exposed algae than by the number of algal cells per unit water volume. As various species of phytoplankton are suspended in the marine environment, we may be able to determine the clearance activity of oysters by detecting the biovolume of all the phytoplankton in the field without considering the species of the algae, except where algal species fatally toxic to bivalves (e.g. Heterocapsa circularisquama and Karenia mikimotoi; Matsuyama et al. 1999) are present.

As mentioned above, the peak clearance rates by the oysters occurred at a biovolume of about $1.0 \times 10^{6} \mu^{3}$ $\mathrm{mm}^{-3}$ for all 3 species of algae used in the present study. However, the maximum clearance rate values by oysters of the biovolume of algae was remarkably lower for oysters exposed to Chattonella antiqua (14.4 $\left.\mathrm{l} \mathrm{h}^{-1} \mathrm{~g}^{-1} \mathrm{DW}\right)$ than for oysters exposed to either C. marina (34.0 $\left.\mathrm{l} \mathrm{h}^{-1} \mathrm{~g}^{-1} \mathrm{DW}\right)$ or Chaetoceros gracilis (26.7 $\left.\mathrm{l} \mathrm{h}^{-1} \mathrm{~g}^{-1} \mathrm{DW}\right)$ (Fig. 5b). According to this result, we suggest this characteristic of $C$. antiqua cells is a possible cause of such a low clearance rate for this alga. Jenkinson et al. (2007) reported that C. antiqua cells show the strongest tendency to clog fish gills among several algal species examined (Skeletonema costatum, Chaetoceros sp., Thalassiosira minima, Heterosigma akashiwo and C. antiqua). It is known that C. antiqua cells are coated with thick glycocalyx, and this substance has high viscosity (Yokote \& Honjo 1985). Glycocalyxes, as well as diffuse colloidal extracellular polymeric substances present in Chattonella cultures, are major factors that restrict the flow of water through fish gills (Jenkinson et al. 2007). In the present study, both Chattonella species would have had glycocalyx coating their cell surfaces. However, $C$. antiqua is more than twice the size of $C$. marina (Table 1); therefore, we speculate that there is probably more glycocalyx on the surfaces of $C$. antiqua cells than on $C$. marina cells, which suggests that the $C$. antiqua cells probably have higher viscosity than the C. marina cells. This high viscosity of $C$. antiqua might have been responsible for the low peak clearance rates by the oysters; $C$. antiqua cells adhere easily and slip very little on oyster gill surfaces. However, further study is needed to describe this phenomenon.

Alexander et al. (2008) hypothesized that the raphidophytes Chattonella subsalsa and Heterosigma akashiwo would not be recognized as prey by the oyster Crassostrea ariakensis, based on the investigation of oyster feces and pseudofeces. Globular cells were observed in the feces and pseudofeces of oysters fed C. subsalsa and $H$. akashiwo; such globular cells are presumably hemocytes (Alexander et al. 2008). The direction of migration of phagocytic hemocytes is regulated by the nature of endocytosed material (Cheng 1996). Hemocytes would enter the lumen of the alimentary tract to take up nutrients and particles and then, if the endocytosed material was nutritious, migrate into deeper tissues to deliver nutrients. Conversely, hemocytes containing waste or toxic material would migrate out of tissues (Cheng 1996). Although Alexander et al. (2008) speculated that globular cells are hemocytes, there is no evidence to support this speculation. Actually, Alexander et al. (2008) suggested the possibility that the globular cells could be partially digested material such as algae or heterotrophic protists. Thus, it is uncertain whether oysters introduce Chattonella cells into their body. In the present study, immunohistological observations of the digestive glands of the oysters and analysis of their phytopigment content revealed that Chattonella cells cleared from the water during the exposure period entered the digestive glands of the oysters and were assimilated into their bodies by phagocytosis (Figs. 6 \& 7), which show that Chattonella cells are assimilated by the oyster.

Consequently, our results indicate that Chattonella marina and $C$. antiqua possess no harmful toxins that injure the oyster. In other words, both Chattonella species are good food for oysters. Perhaps the oyster is a useful organism that can clear the fish-killing Chattonella species from the environment before these harmful algae become abundant.

Acknowledgements. The authors thank Dr. Y. Matsuyama for providing helpful advice on these experiments. We are also grateful to Drs. Y. Kotani and M. Aritaki for revising the manuscript and giving useful suggestions.

\section{LITERATURE CITED}

Ahmed MS, Khan S, Arakawa O, Onoue Y (1995) Properties of hemagglutinins newly separated from toxic phytoplankton. Biochim Biophys Acta 1243:509-512

Alexander JA, Stoecker DK, Meritt DW, Alexander ST and others (2008) Differential production of feces and pseudofeces by the oyster Crassostrea ariakensis when exposed to diets containing harmful dinoflagellate and raphidophyte species. J Shellfish Res 27:567-579

Backe-Hansen P, Dahl E, Danielssen DS (2001) On the bloom 
of Chattonella in the North-Sea/Skagerrak in April-May, 1988. In: Hallegraef GM, Blackburn SI, Bolch CJ, Lewis RJ (eds) Harmful Algal Blooms 2000. Intergovernmental Oceanographic Commission of UNESCO, Paris, p 78-81

Baden DG (1989) Brevetoxins: unique polyether dinoflagellate toxins. FASEB J 3:1807-1817

> Bourdelais AJ, Tomas CR, Naar J, Kubanek J, Baden DJ (2002) New fish-killing alga in coastal Delaware produces neurotoxins. Environ Health Perspect 110:465-470

Cheng TC (1996) Hemocytes: forms and functions. In: Kennedy VS, Newell RIE, Eble AF (eds) The eastern oyster Crassostrea virginica. Maryland Sea Grant College, College Park, MD, p 299-333

> Connell LB (2000) Nuclear ITS region of the alga Heterosigma akashiwo (Chromophyta: Raphidophyceae) is identical in isolates from Atlantic and Pacific basins. Mar Biol 136:953-960

Connell L (2002) Rapid identification of marine algae (Raphidophyceae) using three-primer PCR amplification of nuclear internal transcribed spacer (ITS) regions from fresh and archived material. Phycologia 41:15-21

de Zwaan A, Eertman RHM (1996) Anoxic or aerial survival of bivalves and other euryoxic invertebrates as a useful response to environmental stress - a comprehensive review. Comp Biochem Physiol 113C:299-312

de Zwaan A, Cortesi P, Cattani O (1995) Resistance of bivalves to anoxia as a response to pollution-induced environmental stress. Sci Total Environ 171:121-125

de Zwaan A, Babarro JMF, Monari M, Cattani O (2002) Anoxic survival potential of bivalves: (arte)facts. Comp Biochem Physiol 131A:615-624

- Demura M, Noël MH, Kasai F, Watanabe MM, Kawachi M (2009) Taxonomic revision of Chattonella antiqua C. marina and C. ovata (Raphidophyceae) based on their morphological characteristics and genetic diversity. Phycologia 48:518-535

Hada Y (1974) The flagellata examined from polluted water of the Inland Sea, Setonaikai. Bull Plankton Soc Jpn 20: $112-125$

Hallegraeff GM, Hara Y (2003) Taxonomy of harmful marine raphidophytes. In: Hallegraeff GM, Anderson DM, Cembella AD (eds) Manual on harmful marine microalgae. UNESCO Publishing, Paris, p 511-522

Hallegraeff GM, Munday BL, Baden DG, Whitney PL (1998) Chattonella marina raphidophyte bloom associated with mortality of cultured bluefin tuna (Thunnus maccoyii) in South Australia. In: Reguera B, Blanco J, Fernandez M, Wyatt $\mathrm{T}$ (eds) Harmful algae. Intergovernmental Oceanographic Commission, UNESCO, Paris, p 93-96

Hishida Y (1999) Elucidation of some factors in fish death by Chattonella. PhD dissertation, Nagasaki University (in Japanese)

Hishida Y, Katoh H, Oda T, Ishimatsu A (1998) Comparison of physiological responses to exposure to Chattonella marina in yellowtail, red sea bream and Japanese flounder. Fish Sci 64:875-881

Hosoi-Tanabe S, Otake I, Sako Y (2006) Phylogenetic analysis of noxious red tide flagellates Chattonella antiqua, C. marina, C. ovata, and C. verruculosa (Raphidophyceae) based on the rRNA gene family. Fish Sci 72:1200-1208

Imai I, Yamaguchi M, Watanabe M (1998) Ecophysiology, life cycle, and bloom dynamics of Chattonella in the Seto Inland Sea, Japan. In: Anderson DM, Cembella AD, Hallegraeff GM (eds) Physiological ecology of harmful algal blooms. Springer-Verlag, Berlin, p 95-112

Imai I, Yamaguchi M, Hori Y (2006) Eutrophication and occurrences of harmful algal blooms in the Seto Inland Sea,
Japan. Plankton Benthos Res 1:71-84

Jenkinson IR, Shikata T, Honjo T (2007) Modified ichthyoviscometer shows high viscosity in Chattonella culture. Harmful Algae News 35:1-5

Kamikawa R, Masuda I, Oyama K, Yoshimatsu S, Sako Y (2007) Genetic variation in mitochondrial genes and intergenic spacer region in harmful algae Chattonella species. Fish Sci 73:871-880

Kawano I, Oda T, Ishimatsu A, Muramatsu T (1996) Inhibitory effect of the iron chelator desferrioxamine (Desferal) on the generation of activated oxygen species by Chattonella marina. Mar Biol 126:765-771

- Keppler CJ, Lewitus AJ, Ringwood AH, Hoguet J, Staton T (2006) Sublethal cellular effects of short-term raphidophyte and brevetoxin exposures on the eastern oyster Crassostrea virginica. Mar Ecol Prog Ser 312:141-147

Khan S, Arakawa O, Onoue Y (1996) A toxicological study of the marine phytoflagellate, Chattonella antiqua (Raphidophyceae). Phycologia 35:239-244

> Kim D, Kumamoto O, Lee KS, Kuroda A, Fujii A, Ishimatus A, Oda T (2004) Deleterious effect of Chattonella marina on short-necked clam (Ruditapes philippinarum); possible involvement of reactive oxygen species. J Plankton Res 26 : 967-971

> Landsberg JH (2002) The effects of harmful algal blooms on aquatic organisms. Rev Fish Sci 10:113-390

> Marshall JA, Hallegraeff GM (1999) Comparative ecophysiology of the harmful alga Chattonella marina (Raphidophyceae) from South Australian and Japanese waters. J Plankton Res 21:1809-1822

Matsuyama Y, Uchida T, Honjo T (1999) Effects of harmful dinoflagellates, Gymnodinium mikimotoi and Heterocapsa circularisquama, red-tide on filtering rate of bivalve molluscs. Fish Sci 65:248-253

Numaguchi K (2001) Phyto-pigments in the digestive diverticula of juvenile Japanese pearl oyster, Pinctada fucata martensii, as indicator of algal diets feeding. Suisanzoshoku 49:317-322 (in Japanese with English abstract)

> Oda T, Akaike T, Sato K, Ishimatsu A, Takeshita S, Muramatsu T, Maeda H (1992a) Hydroxyl radical generation by red tide algae. Arch Biochem Biophys 294:38-43

Oda T, Ishimatsu A, Shimada M, Takeshita S, Muramatsu T (1992b) Oxygen-radical-mediated toxic effects of the red tide flagellate Chattonella marina on Vibrio alginolyticus. Mar Biol 112:505-509

- Oda T, Ishimatsu A, Takeshita S, Muramatsu T (1994) Hydrogen peroxide production by the red tide flagellate Chattonella marina. Biosci Biotechnol Biochem 58:957-958

Oda T, Moritomi J, Kawano I, Hamaguchi S, Ishimatsu A, Muramatsu T (1995) Catalase- and superoxide dismutaseinduced morphological changes and growth inhibition in the red tide phytoplankton Chattonella marina. Biosci Biotechnol Biochem 59:2044-2048

Oda T, Nakamura A, Shikayama M, Kawano I, Ishimatsu A, Muramatsu T (1997) Generation of reactive oxygen species by raphidophycean phytoplankton. Biosci Biotechnol Biochem 61:1658-1662

Oda T, Nakamura A, Okamoto T, Ishimatsu A, Muramatsu T (1998) Lectin-induced enhancement of superoxide anion production by red tide phytoplankton. Mar Biol 131: 383-390

Okaichi T (1989) Red tide problems in the Seto Inland Sea, Japan. In: Okaichi T, Anderson DM, Nemoto T (eds) Red tides: biology, environmental science, and toxicology. Elsevier, New York, NY, p 137-142

> Plakas SM, El Said KR, Jester ELE, Granade HR, Musser SM, Dickey RW (2002) Confirmation of brevetoxin metabolism 
in the Eastern oyster (Crassostrea virginica) by controlled exposures to pure toxins and to Karenia brevis cultures. Toxicon 40:721-729

Ringwood AH, Conners DE, Hoguet J (1998) Effects of natural and anthropogenic stressors on lysosomal destabilization in oysters Crassostrea virginica. Mar Ecol Prog Ser 166: 163-171

Shimada M, Murakami TH, Imahayashi T, Ozaki HS, Toyoshima T, Okaichi T (1983) Effects of sea bloom, Chattonella antiqua, on gill primary lamellae of the young yellowtail, Seriola quinqueradiata. Acta Histochem Cytochem 16: 232-244

Shimada M, Shimano R, Murakami TH, Yoshimatsu S, Ono C (1989) Red tide, Chattonella antiqua, reduces cytochrome c from horse heart. In: Okaichi T, Anderson DM, Nemoto T (eds) Red tides: biology, environmental science, and toxicology. Elsevier, New York, NY, p 443-446

Shimada M, Akagi N, Nakai Y, Goto H and others (1991) Free radical production by the red tide alga, Chattonella antiqua. Histochem J 23:361-365

Shimada M, Kawamoto S, Nakatsuka Y, Watanabe M (1993) Localization of superoxide anion in the red tide alga Chattonella antiqua. J Histochem Cytochem 41:507-511

Strickland JDH, Parsons TR (1968) A practical handbook of seawater analysis. Fish Res Board Can Bull 167, Ottawa

Sun J, Liu DY (2003) Geometric models for calculating cell biovolume and surface area for phytoplankton. J Plankton Res 25:1331-1346

Tanaka K, Yoshimatsu S, Shimada M (1992) Generation of superoxide anions by Chattonella antiqua: possible causes for fish death caused by 'Red Tide'. Experientia 48: 888-890

- Tanaka K, Muto Y, Shimada M (1994) Generation of superoxide anion radicals by the marine phytoplankton organism, Chattonella antiqua. J Plankton Res 16:161-169

Tang JYM, Anderson DM, Au DWT (2005) Hydrogen peroxide is not the cause of fish kills associated with Chattonella marina: cytological and physiological evidence. Aquat Toxicol 72:351-360

Toyoshima T, Ozaki HS, Shimada M, Okaichi T, Murakami TH (1985) Ultrastructural alterations on chloride cells of the yellowtail Seriola quinqueradiata, following exposure to the red tide species Chattonella antiqua. Mar Biol 88: $101-108$

Woo SPS, Liu WH, Au DWT, Anderson DM, Wu RSS (2006) Antioxidant responses and lipid peroxidation in gills and erythrocytes of fish (Rhabdosarga sarba) upon exposure to Chattonella marina and hydrogen peroxide: implications on the cause of fish kills. J Exp Mar Biol Ecol 336:230-241

Yamasaki Y, Nagasoe S, Matsubara T, Shikata T, Shimasaki Y, Oshima Y, Honjo T (2007) Allelopathic interactions between the bacillariophyte Skeletonema costatum and the raphidophyte Heterosigma akashiwo. Mar Ecol Prog Ser 339:83-92

Yokote M, Honjo T (1985) Morphological and histochemical demonstration of a glycocalyx on the cell surface of Chattonella antiqua, a 'naked flagellate'. Experientia 41: 1143-1145

Appendix 1.

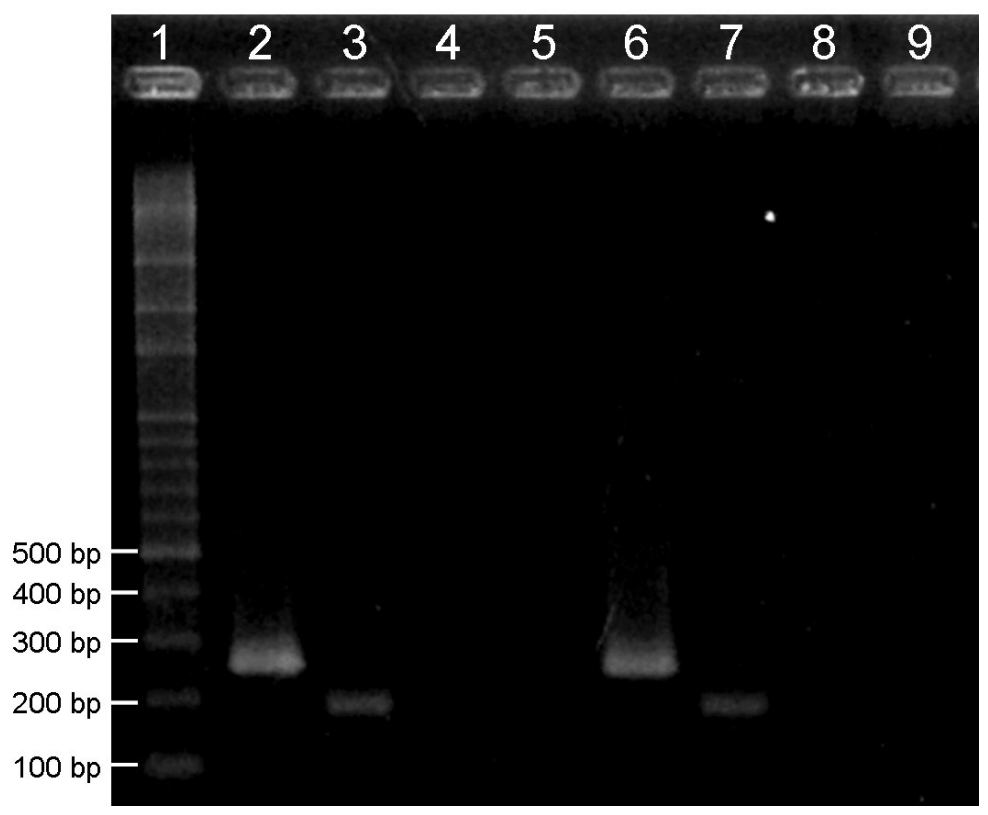

Fig. A1. Raphidophyceae species-specific PCR amplification products. Lane 1, DynaMarker 100 bp ladder (BioDynamics Laboratory) with band size indicated at the left. Lanes 2 to 5, PCR-generated Chattonella antiqua culture products against several primer sets (see below). Lanes 6 to 9, PCR-generated C. marina culture products against the same primer sets. Primer sets: Lanes 2 and 6, Raphidophyceae universal primer mix (oBTG-005B/oBTG-006B); Lanes 3 and $7, C$. antiqua/marina/ovata primer mix (oBTG005B/oBTG-027); Lanes 4 and 8, C. subsalsa primer mix (oBTG-005/oBTG-028); Lanes 5 and 9, Heterosigma akashiwo primer mix (oBTG-005/oBTG030B). See Tables $3 \& 5$ in Connell (2002) for the primer set names and oligonucleotide sequences. With the Raphidophyceae universal primer mix, the PCR amplification product size of both $C$. antiqua and C. marina was $250 \mathrm{bp}$, which is consistent with the result of $C$. antiqua reported by Connell (2002) and different from those of Fibrocapsa japonica (353 bp) and Olisthodiscus luteus (354 bp) (Connell 2002). The C. subsalsa and H. akashiwo primer mixes gave no detectable bands

Editorial responsibility: Riccardo Cattaneo-Vietti, Genova, Italy
Submitted: May 11, 2010; Accepted: September 24, 2010

Proofs received from author(s): December 15, 2010 